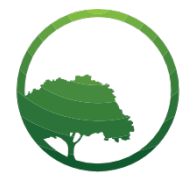

Research in Business \& Social Science

IJRBS VOL 8 NO 6 ISSN: 2147-4478

Business \& Social Science

Available online at www.ssbfnet.com IJRBS

Journal homepage: https://www.ssbfnet.com/ojs/index.php/ijrbs

\title{
Effect of infrastructure development in the program of simultaneous movement for village development on economic growth
}

\author{
Irwan Effendi ${ }^{a}{ }^{*}$, Leni Sepri Yanti ${ }^{b}$, Indah Listiana ${ }^{c}$ \\ Crossref \\ a,b,c Department of Agricultural Economics and Social Science College of Agriculture, University of Lampung, Bandar Lampung, Indonesia
}

\begin{tabular}{l} 
A R T I C L E IN F O \\
\hline Article history: \\
Received 28 August 2019 \\
Received in revis. form 22 Sept.2019 \\
Accepted 08 October 201919 \\
\hline Keywords: \\
Direct Cash Transfer for Community \\
Community Initiative \\
Economic Growth \\
JEL Classification: \\
L19
\end{tabular}

\section{A R T ICLE IN F O}

Article history:

Received in revis. form 22 Sept.2019

\begin{abstract}
A B S T R A C T
The Regency of Tulang Bawang develops a program called Simultaneous Movement for Village Development (Gerakan Serentak Membangun Kampung), that is a movement carried out by, from, and for the community of Tulang Bawang to do the right thing together in an effort to accelerate the development of village infrastructure for economic development of village community.Infrastructure limitation leads to the high poverty rate in rural areas. The study of Simultaneous Movement for Village Development Program or Gerakan Serentak Membangun Kampung (GSMK) aims to assess the effect of Direct Cash Transfer for Community (BLM, Dana Bantuan Langsung Masyarakat), and community initiative in GSMK Program on the economic growth of the community in Tulang Bawang Regency. The type of research applied was quantitativeresearch using multiple regression analysis. This study was conducted using secondary data in 2011-2016 sourced from Lampung dalam angka, the result of previous studies, and other supporting data. Moreover, the data required in this study included the total amount of BLM and community initiative in the GSMK Program conducted in Tulang Bawang Regency, and community initiative. The study conducted in Tulang Bawang Regency showed that: (1) Therewas significantcorrelation between Direct Cas Transfer for Community and Community Initiative on Economic Growth Rate of Community; (2) Direct Cash Transfer for Community significantly affected the Gross Regional Domestic Product (PDRB)at confidence level of $99 \%$, and(3) Community Initiative did not significantly affect economic growth rate of community since confidence level only reached a value of $11.5 \%$.
\end{abstract}

\section{Introduction}

The government of Tulang Bawang Regency considers to develop the Program Policy in order to promote the Movement for Development by, from, and for community by utilizing the potency and existing social institution such as Piil Pesenggiri, Sakai Sambayan, Nengah Nyappur, Gotong Royong (mutual cooperation), Persaudaraan (brotherhood), and Kebersamaan (togetherness), also social values typically applied in Tulang Bawang. In an effort to bring this Policy of Development Program as a Model of Community Based Development with typical characteristic of Tulang Bawang Regency, this Program of stimulant provision is called the Program of Simultaneous Movement for Village Development (Program Gerakan Serentak Membangun Kampung), that is a movement conducted by, from, and for the community of Tulang Bawang to do the right thing together in an effort to accelerate the development of village infrastructure for economic development of village community.

The term Gerakan Serentak Membangun Kampung (GSMK) in this Movement for Development is also related to socialize the motto of Tulang Bawang Regency Development as stated in the Regional Regulation Number 20 in 2004. Availability of adequate infrastructure in a region will attract investors to invest their capital, resulting in employment opportunity which eventually will cut off vicious circle of poverty. However, infrastructure becomes one of maim problems in village development. Under-development of rural infrastructure leads to limited access required, causing high poverty rate in rural area.

* Corresponding author. ORCID ID: 0000-0001-7916-1891

Peer review under responsibility of Bussecon International Academy.

(C) 2019 Bussecon International. Hosting by SSBFNET- Center for Strategic Studies in Business \& Finance. All rights reserved.

https://doi.org/10.20525/ijrbs.v8i6.505 
Problem encountered in improving rural community welfare is included to several major problems, namely (1) less-developed rural community life due to limited access obtained by community, particularly women to productive resource, such as land, capital, infrastructure, and technology, as well as access to public facility and market; (2) limited facility and infrastructure service of rural settlement, like drinking water, sanitation, waste management, and other environmental facilities; (3) limited capacity of government institution at local level and socioeconomic institution to support the improvement of rural development resources; and (4) poor correlation between urban and rural economic activities which results in increasing economic gap and infrastructure service gap between regions.

Tulang Bawang Regency is heading towards the increasing process of national economic growth in accordance with its optimal capacity. Even though the policy of infrastructure development in Indonesia has been implemented for quite a long time along with high cost and quite significant contribution to the increasing economic growth, there are still problems found in many regions in Indonesia, such as weak planning, inadequate quantity and low quality (I Firmasnyah, 2009). One of problems faced in increasing local economy is lacking of adequate infrastructure, particularly in rural area. The condition of rural infrastructure service is still considered insufficient.

Problem Formulation: 1. How is the effect of Direct Transfer Cash for Community (BLM) in infrastructure development included in the program of Simultaneous Movement for Village Development (GSMK) on economic growth of community 2. How is the effect of community initiative on economic growth of the community of Tulang Bawang Regency. The goals of Simultaneous Movement for Village Development (GSMK) Program include: (1) To assess whether Direct Transfer Cash for Community (BLM) in Program of Simultaneous Movement for Village Development (GSMK) affects economic growth of the community of Tulang Bawang Regency (2) To assess whether community initiative in Program of Simultaneous Movement for Village Development (GSMK) affects economic growth of the community of Tulang Bawang Regency.

\section{Literature Review}

\section{Program of Simultaneous Movement for Village Development (GSMK)}

Program of Simultaneous Movement for Village Development is an effort conducted by the Regency Government to support the development program by, from, and for the community by means of typical social institution in Tulang Bawang, by providing direct cash transfer to village community for facility and infrastructure development that is necessary and will benefit the community.

Direct Cash Transfer for Community distributed per village through GSMK that ranged from Rp.175 million in 2011 to 225 million in 2016 is stimulant from the central government provided for village community as a stimulus for improvement of infrastructure and economy of village community. Thus, village community is given a big role to plan, perform, control, use, and manage their own village. Implementation of Simultaneous Movement for Village Development Program is expected to raise critical awareness and community independence by preparing village priority proposal and community work plan in accordance with its requirement and problem.

Program is conducted in stages and gradual, starting from preparing, planning, implementing, monitoring, and controlling, also utilizing and maintaining the program, in which each implementation involves community group as the actor to conduct GSMK Program in the village.

Direct Cash Transfer for Community (BLM) is assistance provided by the Government of Tulang Bawang Regency for village community to be directly managed by village community according to the designated purpose. This Direct Cash Transfer is a provision of stimulus fund through the Program of Direct Cash Transfer for Community (BLM) allocated to village in accordance with the decision of Tulang Bawang Regent based on the proposal proposed by the Sub-district and recommendation of the coaching group that has been coordinated with the Regency (BPS, 2016).

Community Initiative Fund (Dana Swadaya Masyarakat) is defined as the ability of community or group of people to voluntarily gather in a group due to bonds that unify them, namely similar interest and need, thus the group has the same goal to achieve together. Community initiative could be in the form of labor, materials, fund, and other thing that are converted of at least $20 \%$ of cash transfer fund (BLM) of GSMK program since the fund is only a stimulant.

According to Christenson and Robinson (in Firmansyah, 2009), Community Development is a process where community living in certain location develop their initiative to conduct a social action (with or without intervention) to change their economic, social, culture, and environmental situation. Community empowerment pattern required today is such empowerment that highly supports community aspiration and potency to carry out self-initiative activity, namely empowerment pattern with characteristic of bottom-up intervention that appreciate and acknowledge low-level community to have potency to fulfil their need, solve their problem, and conduct productive efforts by applying the principle of self- initiative and togetherness (Emmy, 2014).

Infrastructure development is an important and vital aspect to accelerate the process of national development. Infrastructure plays essential role as one of wheels that drives economic growth. Infrastructure condition in under-developed region encounters many problems, such as non-optimal infrastructure according to the Standard of Minimum Service (SPM). 
Basri and Munandar (2009) mentioned that infrastructure determines the basis of sustainability and acceleration of development. Infrastructure availability will stimulate development in a region or a country. Apparently, faster and larger economic development to be driven requires more infrastructure facility. Hence, unavailability of appropriate infrastructure obviously will hinder the activity of economy or development in general.

According to Gie (2002), to accelerate economic recovery in Indonesia, development of facility and infrastructure as well as the service should be implemented by considering criteria as follows: 1. Create employment opportunities, both directly and indirectly, 2. Support regional economic development, 3. Generate economic benefit as much as possible for community living around the infrastructure project, and 4. Profitable in term of economy and finance, thus attracting domestic and foreign investor.

The basic policy implemented in infrastructure development includes: (1) policy to maintain the level of infrastructure service, (2) policy to continue restructuration and reformation in infrastructure, and (3) increase community accessibility to infrastructure service.

Gaduh (2010) reported that under-developed infrastructure in rural area may inhibit economic growth in a region since it will limit productive growth and hinder the development of human capital. Consideration of the large role of infrastructure development in rural poverty alleviation encourages central government and donor institutions to provide assistance in certain amount to support projects, e.g. infrastructure development.

Transportation is a connecting facility or thing that connects production area and market, or bring near production area and market, or often it is said that transportation bridges the gap between producer and consumer. The role of transportation is really important as connecting facility, bring closer, and bridge the gap between parties need one another (Adisasmita, 2011). The role of infrastructure in transportation aspect includes the role to overcome obstacles hindering the flow of goods and people, both in land, sea, and air (Susanto, 2009).

Positive externalities in infrastructure appear as Spillover Effect in the form of increasing production in companies and agricultural sector without increasing input of capital and labor or increasing the level of technology. Building infrastructure will increase productivity level of company and agricultural sector. One of the most visible infrastructure development is road construction. According to the Presidential Decree Number 42 in 2005 about the Committee for the Acceleration of Infrastructure Provision, several types of infrastructure in which its provision should be regulated by the government includes infrastructure of transportation, infrastructure of road, infrastructure of irrigation, infrastructure of drinking water and sanitation, infrastructure of telematics, infrastructure of electricity, and infrastructure of oil and gas transportation. The classification of infrastructures above is categorized as basic infrastructure since it is required by wider society, thus its provision should be regulated by the government. Infrastructure plays an essential role since it connects many centers of economic activity and its buffer zone.

Grigg (1988) mentioned that infrastructure is a physical system that provides transportation, irrigation, drainage, building, and other public facilities required to fulfil human basic needs, both social and economic needs. This definition refers to infrastructure as a system. In an infrastructure system, its part in the form of facility and infrastructure (network) is unseparated one another. It is due to the fact that infrastructure in a system that supports both social and economic system that connects to environmental system. Availability of infrastructure provides impact on social and economic system existing in the society. Therefore, infrastructure should be comprehended as the basis to decide any policy (Kodoatie, 2005).

Infrastructure Development and Economic Growth are closely related to infrastructure development that has the ability to stimulate regional growth, in term of economic and social aspect. The study conducted in the US by Aschauer in 1989 and Munnell in 1990 showed that the rate of return to infrastructure investment on economic growth reached $60 \%$ (Dikun, 2003).

\section{Research and Methodology}

This study used secondary data of fiscal year 2011-2016 sourced from Lampung dalam angka (Lampung in Number) and other related sources, namely scientific journals and result of previous study. Furthermore, data required in this study included total amount of direct cash transfer (BLM) and community initiative of Simultaneous Movement for Village Development (GSMK) Program in Tulang Bawang Regency and Community initiative.

\section{Research Variable}

Independent variable in this study: (1) Total amount of direct cash transfer for community (BLM) in the Program of Simultaneous Movement for Village Development (GSMK), (2) Number of Community Initiative in the Program of Simultaneous Movement for Village Development (GSMK). Dependent variable in this study was GRDP or PDRB per capita: PDRB per capita in this study was measured through Gross Regional Domestic Product based on constant price of 2011, per capita of each province in thousand rupiah/capita. Result of data estimation with dependent variable of PDRB per capita will be used to explain the effect of direct cash transfer for community (BLM) and community initiative investigated on economic growth since the output estimation is in the form of elasticity that shows how changes in infrastructure affect changes in GRDP per capita. To sum, changes in GRDP per capita is known as economic growth. 
Table 1: Research Data

\begin{tabular}{|c|c|c|c|}
\hline No & Type of data & Unit & Source \\
\hline 1 & $\begin{array}{l}\text { Gross Regional Domestic Product (PDRB) of } 2016 \\
\text { constant price according to Tulang Bawang Regency }\end{array}$ & Thousand Rupiah/ capita & $\begin{array}{l}\text { Online publication of BPS } \\
2016\end{array}$ \\
\hline 2. & Direct Cash Transfer for Community (BLM) & Thousand Rupiah & $\begin{array}{l}\text { Report of Management } \\
\text { Consultant for GSMK } \\
\text { Program }\end{array}$ \\
\hline 3. & Community Initiative & Thousand Rupiah & $\begin{array}{l}\text { Report of Management } \\
\text { Consultant for GSMK } \\
\text { Program }\end{array}$ \\
\hline
\end{tabular}

\section{Analysis Tools}

Analysis in this study was applied through the approach of quantitative descriptive to investigate the effect of independent variable on dependent variable using multiple linear regression and classical assumption test. Descriptive approach is experiment that only describes or explains phenomena resulted from the data investigated in a way that is short, simple, and informative without drawing general conclusion. The effect of direct cash transfer and community initiative on Economic Development, correlation between direct cash transfer as well as community initiative and GRDP was analyzed using multiple linear regression. Factors expected to affect GNRB included direct cash transfer or BLM (X1) and community initiative (X2), in a mathematic model is presented as follows:

Note:

$$
\mathrm{Yi}=\beta 0+\beta 1 \mathrm{X} 1+\beta 2 \mathrm{X} 2+\mathrm{e}
$$

$\mathrm{Yi}=\mathrm{GRDP}$

$\beta 0=$ Intercept

$\beta 1-\beta 2=$ Coefficient of independent variable

$\mathrm{X} 1=\mathrm{BLM}(\mathrm{Rp})$

$\mathrm{X} 2$ = Community initiative $(\mathrm{Rp})$

\section{Result and Discussion}

One of important indicators to determine economic development of a region in certain period can be carried out by observing the real growth rate of all business fields in aggregate in the relevant year. Economic growth is an indicator that is able to show the movement of economic growth of a region. At high growth rate, it is expected that the productivity and income gained by the community will increase along with employment creation and opportunity. However, high growth of employment cannot not ensure that employment created will play a big role in the formation of GRDP value, in term of output.

The value of GRDP of Tulang Bawang Regency in 2011-2016 increased continuously. In 2011, GDRP of Tulang Bawang Regency reached Rp. 10,284,191.09 million. In 2012, GRDP of Tulang Bawang Regency amounted to Rp. 10,827,944.73 million. In 2013, GRDP of Tulang Bawang Regency reached 11,559,174.33 million. In 2014, GRDP of Tulang Bawang Regency amounted to 12,199,160.20, while it was 12,811,520.10 in 2015 and 13,505,401.04 in 2016.

\section{Allocation of Direct Transfer Cash (BLM Fund) of GSMK Program}

According to the Decree of Tulang Bawang Regent, allocation of BLM of Simultaneous Movement for Village Development (GSMK) Program amounted to Rp.26,075,000,000 (2011), Rp.27,750,000,000 (2012), Rp. 30,000,000,000 (2013), Rp.31,800,000,000 (2014), Rp. 35,250,000,000 (2015), and 35,700,000,000 (2016). The budget was allocated to fund the activity of physical facility and infrastructure development in the village. Allocation of BLM fund of GSMK Program in Tulang Bawang Regency in Fiscal Year 2014 using community initiative is shown in Figure below. The amount of BLM of GMSK Program in Tulang Bawang Regency during Fiscal Year 2011-2016 and Community Initiative are presented in Table 1.

Table 1: Graph of Comparison between Direct Cash Transfer of GSMK Program in Tulang Bawang Regency during 2011 - 2016

\begin{tabular}{|c|c|c|c|c|c|c|}
\hline \multirow[t]{2}{*}{ Note } & \multicolumn{6}{|c|}{ Year } \\
\hline & 2011 & 2012 & 2013 & 2014 & 2015 & 2016 \\
\hline $\begin{array}{l}\text { Total amount of direct cash } \\
\text { transfer/BLM (Rp) }\end{array}$ & $\begin{array}{c}26,075,000,0 \\
00\end{array}$ & $\begin{array}{l}27,750,000,0 \\
00\end{array}$ & $\begin{array}{l}30,000,000,0 \\
00\end{array}$ & $\begin{array}{c}31,800,000,0 \\
00\end{array}$ & $\begin{array}{c}35,250,000,0 \\
00\end{array}$ & $\begin{array}{c}35,700,000,0 \\
00\end{array}$ \\
\hline Community initiative (Rp) & $\begin{array}{c}7,822,500,00 \\
0\end{array}$ & $\begin{array}{c}7,668,750,00 \\
0\end{array}$ & $\begin{array}{c}8,226,466,00 \\
0\end{array}$ & $\begin{array}{c}9,705,908,00 \\
0\end{array}$ & $\begin{array}{c}10,575,000,0 \\
00\end{array}$ & $\begin{array}{c}10,816,250,0 \\
00\end{array}$ \\
\hline
\end{tabular}


Based on Table 1, allocation of BLM and community initiative of GSMK Program increased over year. This condition is due to an extremely high level of community participation in the program of Simultaneous Movement for Village Development.

Calculation was conducted using multiple linear regression analysis tool through the method of multicollinearity using SPSS 16.00 to investigate whether correlation between independent variables exist or not. Effect of Direct Cash Transfer for Community and Community Initiative on economic growth in Tulang Bawang Regency during the period 2011-2016 was measured to obtain the result as follows:

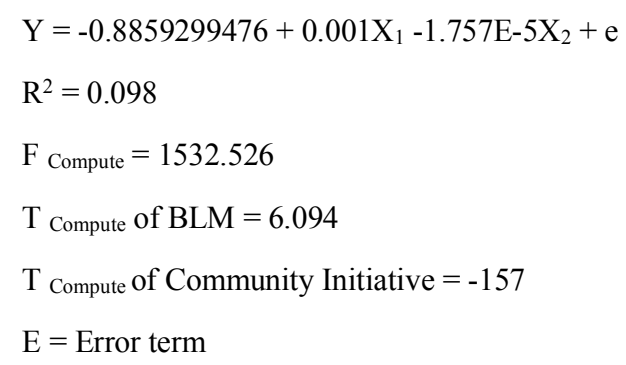

Based on the result of calculation using the multiple linear regression model, coefficient $\left(\mathrm{R}_{2}\right)$ of 0.098 indicates that independent variables observed had significant effect of $99.80 \%$ on economic growth in Tulang Bawang Regency, while the remaining $0.20 \%$ was affected by factors outside of the study. Therefore, this model was found to be able to explain dependent variable.

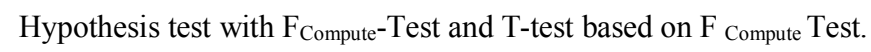

$\mathrm{F}_{\text {Compute }}=1532.526$, significant $=0.000$, It means that the variable of Direct Cash Transfer of GSMK Program $\left(\mathrm{X}_{1}\right)$ and Community Initiative $\left(\mathrm{X}_{2}\right)$ altogether significantly affected GRDP (economic growth) at confidence level of $99 \%$.

Based on $\mathrm{T}_{\text {Compute-Test: }}$

$\checkmark \quad$ Constant -4.591 , sig 0.019

It means that constant or intercept has a significant effect at confidence level of $99 \%$, hence when all X variables equal 0, GRDP obtained amounted to

-8859299.476 unit.

\section{Direct Cash Transfer for Community (X1)}

Direct Cash Transfer (X1) of 6.094 with significance of 0.009 indicates that Direct Cash Transfer for Community (BLM) significantly affected GRDP at confidence level of 99\%, if BLM fund increases one unit, GDRP will increase by 0.001 .

BLM was found to have positive elasticity coefficient of 0.001 , indicates that every additional $1 \%$ of BLM, GDRP per capita will increase by $0.001 \%$, ceteris paribus. Probability value of BLM variable was found to be lower than 0.01 at confidence level of $99 \%$ or significance level of 0.01, showing that the variable of Direct Cash Transfer (BLM) statistically affected economic growth. Based on the result of model estimation, it is conclude that BLM fund positively and significantly affected economic growth.

Direct Transfer Cash or BLM fund positively affected economic growth since BLM fund was used to accelerate the development process of village community, and in the development process of this Simultaneous Movement for Village Development Program, many labors were absorbed, thus declining unemployment rate in Tulang Bawang Regency. Moreover, this program could also increase income of the community of Tulang Bawang Regency around the location of infrastructure development. Program of GSMK helps accelerating the development of facility and infrastructure located around the community settlement since community also conducted planning, implemented, and controlled to ensure the activity run effectively and efficiently.

\section{Effect of Community Initiative on economic growth}

Community initiative (X2) -.157 with significance of 0.885 , means that community initiative did not have significant effect on GRDP since confidence level obtained only reached $11.5 \%$

Probability value of the variable of community initiative was 0.88 for significance level of above $5 \%$, thus the variable of community initiative did not significantly affect economic growth. Based on the estimation result, the Program of Simultaneous Movement for Village Development during 2011-2016 was considered to have no statistical correlation with economic growth. It is due to low community participation in term of planning, control, and evaluation of GSMK program. Many people did not participate in the implementation of GSMK Program, thus community initiative both in term of capital and labor was low. Eventually, this led to insignificant effect of community initiative on economic growth of Tulang Bawang Regency.

Other factor causing community initiative to be not related to the growth rate is inappropriate development of facility and infrastructure. Hence, facility and infrastructure development should be built suitable to the needs of community. This effort is 
expected to raise community awareness to participate in the Program of Simultaneous Movement for Village Development (Gerakan Serentak Membangun Kampung) in Tulang Bawang Regency.

\section{Conclusions}

There is significant correlation between Direct Cash Transfer for Community (BLM) and Community Initiative on Economic Growth Rate of community. Direct Cash Transfer (X1) significantly affected the Gross Regional Domestic Product (PDRB) at confidence level of $99 \%$. Community Initiative did not significantly affect economic growth rate of community since confidence level only reached a value of $11.5 \%$

\section{References}

Adisasmita, Rahardjo. 2013. Teori-Teori Pembangunan Ekonomi; Pertumbuhan Ekonomi dan Pertumbuhan Wilayah. Yogyakarta: Graha Ilmu.

BPS [Badan Pusat Statistik]. 2016. Tulang Bawang Dalam Angka.

Basri, Faisal dan Haris Munandar, 2009. Lanskap Ekonomi Indonesia (kajian dan Renungan terhadap Masalah-masalah Struktural, Transformasi Baru, dan Prospek Perekonomian Indonesia. Jakarta: Kencana Prenada Media Group

Boediono. 1999. Teori Pertumbuhan Ekonomi. Yogyakarta: BPFE-Yogyakarta

Dikun, Suyono. (2003) Infrastruktur Indonesia : Sebelum, Selama, dan Pasca Krisis. Jakarta: Kementerian Negara PPN/BAPPENAS

Emmy, Sovia, 2014. Pemberdayaan Masyarakat dalam Era Global. http://www. ppsw.or.id/index.php/19-berita-terbaru/204pemberdayaan-masyarakat-dalam-eraglobal. (11 Mei. 2014

Firmansyah, Herlan, (2009) "Pertumbuhan Ekonomi”, 21 April 2009 http://erlanabuhanifa.blogspot.com/2009/04/bahan-kuliahpertumbuhan-ekonomi.html di akses tanggal 12 Februari 2013.

Gaduh, Arya, 2010. Kapasitas Desa dalam Memelihara Infrastruktur Bukti dari Perdesaan Indonesia. http://www.pnpmsupport.org/id/publication/ kapasitas - desa - dalam - memelihara - infrastruktur - bukti - bukti -dari-perdesaan-indonesia (30 Mar. 2014)

Gie, Kwik Kian, 2002. Pembiayaan Pembangunan Infrastruktur dan Pemukiman. http: // www. bappenas. go. id/ index. Php / 2255/ (31Mar.2014)

Grigg, N. 1988, Infrastructure Engineering and Management, John Wiley \& Sons

Kodoatie, Robert (2005).Pengantar Manajemen Infrastruktur. Yogyakarta: Pustaka Pelajar

Susanto, Bambang, 2009. Memacu Infrastruktur Di Tengah Krisis, Cetakan Pertama, Pustaka Bisnis Indonesia, Jakarta. 